\title{
Do tenentismo à ANL: a disputa de projetos para o Brasil
}

From the Brazilian lieutenant's movement

to the National Liberation Alliance: the dispute over projects for Brazil

\section{Dioge alceno konird*}

DOI: https://doi.org/10.4322/principios.2675-6609.2022.163.003

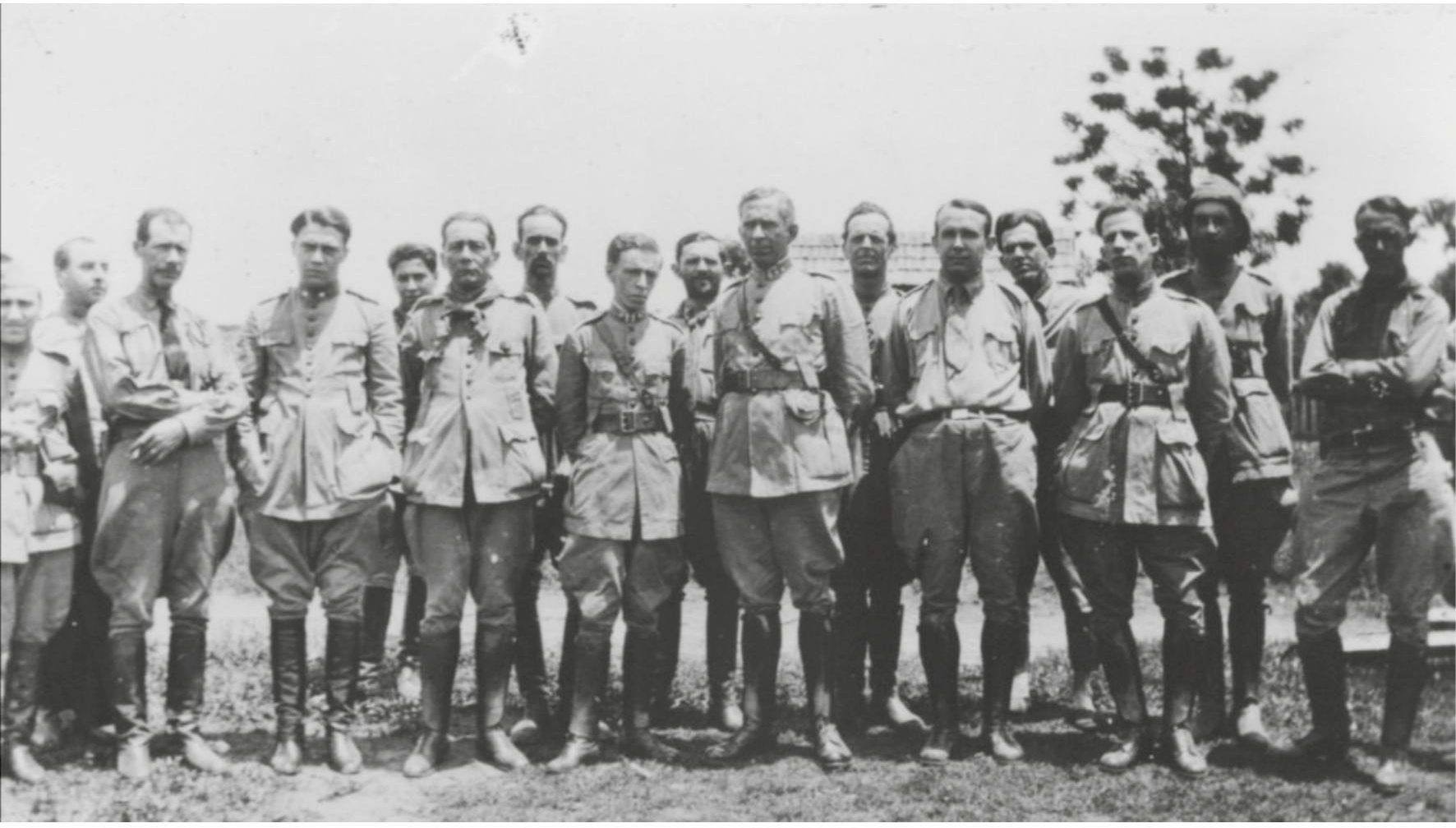

Grupo de militares alinhados ao tenentismo e participantes da Revolução de 1930, que levou Getúlio Vargas ao poder. Ao centro, Miguel Costa (o mais alto) 


\section{RESUMO}

Entre 1922 e 1935, a formação social do Brasil passou por um ciclo revolucionário no qual diversos projetos de nação disputaram o poder político. Esse processo histórico se deu no âmbito da crise política e social da Primeira República, somada à crise mundial do capitalismo. Este artigo objetiva demonstrar parte da participação militar na história política brasileira republicana, a fim de se entender o surgimento do movimento tenentista e seu protagonismo no movimento de 1930, bem como os propósitos da Aliança Nacional Libertadora (ANL), organizada em 1935, herdeira de parte da tradição tenentista e parte do movimento comunista.

Palavras-chave: Tenentismo. Aliança Nacional Libertadora. Revolução. Brasil.

\section{ABSTRACT}

From 1922 to 1935 , the social formation of Brazil went through a revolutionary cycle in which several projects of nation were competing for political power. This historical process took place in the context of the political and social crisis of the First Republic, added to the world crisis of capitalism. This article aims to demonstrate part of the military participation in Brazilian republican political history, in order to understand the emergence of the lieutenant's movement and its role in the 1930 movement, as well as the purposes of the National Liberation Alliance (ANL), organized in 1935, which is a legacy of both the lieutenant's tradition and the communist movement.

Keywords: Lieutenant's movement. National Liberation Alliance. Revolution. Brazil. 


\section{INTRODUCÃ̃o}

Diferentemente da maioria dos países latino-americanos, a República brasileira foi uma conquista mais demorada, ao longo no século XIX. Mantendo a herança escravista da colônia, a independência nos legou uma monarquia parlamentar, marcada por um liberalismo conservador com resquícios até a atualidade (KONRAD, 20I5a).

A própria transição do modo de produção escravista para o capitalismo foi carregada de conservadorismo, com os latifundiários prolongando ao máximo a escravidão, impedindo que a luta de classes dos escravos se tornasse alternativa de poder político e garantindo uma República liberal e conservadora, dominada pelos fazendeiros e outras frações da nova burguesia agrária brasileira, mesmo que, com a abolição da escravidão (I888), a República (I889) e a Constituição republicana (I89I), se garantissem as bases do Estado burguês no Brasil (SAES, 1985).

As transformações que ocorreram no Brasil a partir da segunda metade do século XIX expressam as contradições em que se inseria a economia brasileira e sua dependência externa no contexto de surgimento do imperialismo, além das condições internas de desestruturação da escravidão, concomitantemente à falta de força de trabalho escravizada e ao desenvolvimento das forças produtivas de caráter capitalista (KONRAD; RAMOS, I988, p. 26-28), haja vista que, na formação histórica do Brasil pré-Abolição, no último quartel do século XIX, quando o modo de produção escravista em crise chancelou a perda do poder econômico dos fazendeiros do Vale do Paraíba, no Rio de Janeiro, essencialmente escravocratas, começava a desestruturar-se o regime que o sustentava, a monarquia (KONRAD, 20I5a).

Setores médios, no processo de urbanização pelo qual passava o Brasil, vão aderindo à causa abolicionista, somando-se à quase "quatrocentona" luta dos escravizados. Após a Guerra do Paraguai, o Exército sobressaiu como aparato repressivo de Estado de influência nacional e, permeado por ideais positivistas e republicanos, passou a ter protagonismo político, imbuído das consignas "ordem e progresso" e "salvação da nação".

Este artigo objetiva demonstrar parte da participação militar na história política brasileira republicana, a fim de se entender o surgimento do movimento tenentista e seu protagonismo no movimento de 1930, bem como nos propósitos da Aliança Nacional Libertadora (ANL), organizada em 1935.

\section{DE MILITARES PELA REPÚBLICA A MILITARES REPUBLICANOS: O TENENTISMO}

Ainda no Império, "salvar a nação" do atraso escravista e monárquico passou a ser, cada vez mais, uma diretriz dos militares, primeiro os oficiais de baixa patente, por fim os mais graduados. Daí, passando pelas chamadas questões militares e questões religiosas, para o golpe militar de 1989, que proclama a República e explica os governos republicanos de Deodoro da Fonseca e Floriano Peixoto, tivemos um 
tempo histórico muito curto, redefinindo as forças políticas no controle do poder de Estado. Sim, nossa República começa com um golpe militar, inaugurando a tradição de rupturas políticas golpistas tão comuns na nossa formação republicana. Ou seja, em um primeiro momento foram os militares republicanos que assumiram o governo central, seguindo-se os políticos civis do bloco liberal conservador (KONRAD, 20I5a).

Com a proclamação da República, em I5 de novembro de I889, ocorreu a ascensão de partidos republicanos regionalizados, cada qual defendendo os principais interesses de seu estado, uma República caracterizada por Rodrigo Patto Sá Motta como uma forma de reação ao centralismo do Estado imperial (MOTTA, I999, p. 49). Durante esse período, em nível nacional, ganharam um maior destaque os partidos republicanos de São Paulo e de Minas Gerais, que se alternaram na Presidência do país, consolidando a República dos fazendeiros, especialmente da burguesia cafeicultora, que alternará políticos paulistas e mineiros na Presidência da República, ocorrendo a reestruturação das forças políticas no controle do poder central. Num primeiro momento, são os militares republicanos que assumem o governo central, com Deodoro da Fonseca, seguido por Floriano Peixoto. Depois, seguem-se os políticos civis do bloco liberal conservador, marcado pela força política do Partido Republicano Paulista (PRP) e do Partido Republicano Mineiro (PRM) (KONRAD; LIMA, 20I3, p. 55-56).

Com isso, mesmo que os fazendeiros do oeste paulista não chegassem ao governo imediatamente, se apressaram para consolidar seus eixos de poder através da Constituição de I89I, nitidamente uma Carta liberal conservadora. Para os grandes fazendeiros do Sudeste, a chefia do Poder Executivo veio com os governos de Prudente de Morais (I894-I898) e, especialmente, Campos Sales (I898-I902). Aqui, a República, que já nasceu "Velha", se consolidou, estabelecendo a "política dos governadores" (ou presidentes de Estado) e a "política café com leite", tradicionalmente nominadas assim pela maior parte da historiografia (KONRAD, 20I5a).

Na transição do Império para a República, a situação econômica do Brasil não teve mudanças significativas, mas possibilitou-se o alargamento capitalista da economia nacional, mesmo que esse capitalismo nascente já encontrasse sua grande crise entre I892 e I893, afetando o café em uma fase de superprodução. A solução foi dada pelo primeiro governo representante dos grandes fazendeiros, o governo de Campos Sales (I898-I902), o qual estabeleceu a busca de solução política para os revezes do encilhamento, através do acordo do funding loan, bem como a busca por valorizar o café, sobretudo em I906, com o Convênio de Taubaté, aprofundando a subordinação da economia brasileira ao exterior, especialmente ao capital inglês. A consolidação da República dos grandes proprietários fundiários, braços direitos do imperialismo inglês, não livrou o Brasil da crise de acumulação capitalista de fins do século XIX, início do século XX, ao contrário, inseriu-o nela. A superprodução do café afetou o eixo central da economia brasileira, entre avanços e recuos, de I892 a 1929 (KONRAD, 20I5a). 


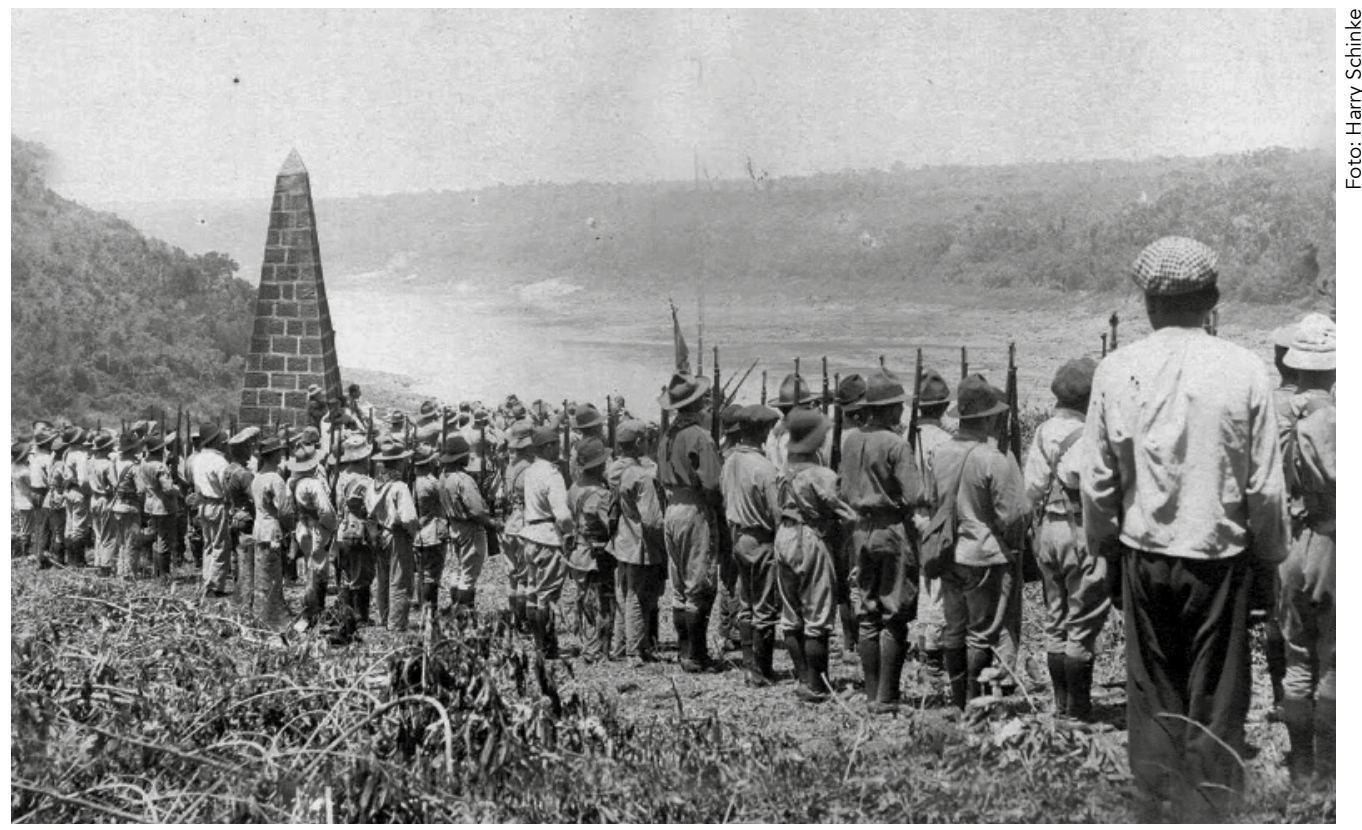

Coluna Prestes: tropas revolucionárias paulistas em Foz do Iguaçu (PR), depois de terem descido de barco pelo rio Paraná para se juntar com as tropas gaúchas lideradas por Luís Carlos Prestes, 1925

Um dos fenômenos políticos mais característicos da Primeira República brasileira foi o "coronelismo" - expressão de uma classe proprietária agrária reacionária originalmente constituída de senhores de escravos e agora aburguesada - que estabelecia um sistema eleitoral elitista e uma força política e militar cuja grande marca era o "voto de cabresto", as constantes fraudes eleitorais e o aprofundamento da "ideologia do favor". Mesmo assim, o impulso industrial, iniciado ainda no Segundo Império, acelerou-se com novas políticas de aumento do mercado interno, sobretudo durante a Primeira Guerra Mundial, de I9I4 a I9I8 (KONRAD; RAMOS, 1988, p. 28-29), possibilitando que, ainda em 1928 , a renda industrial ultrapassasse a renda agrícola (CARONE, s.d., p. I59).

As contradições políticas da Primeira República fortalecerão a "esquerda militar" (MORAES, I99I), não só substanciando os conflitos entre militares e civis, o que explica em parte a ascensão do governo de Hermes da Fonseca (I9IO-I9I4), mas tendo relação direta com a Reação Republicana, um movimento de oposição das classes dominantes brasileiras na Primeira República capitaneado pelos líderes dos estados da Bahia, de Pernambuco, do Rio de Janeiro e do Distrito Federal, lançando Nilo Peçanha contra Artur Bernardes, o candidato da tradicional aliança à Presidência da República, alicerçado politicamente por São Paulo e Minas Gerais. Nessa conjuntura, jovens oficiais do Exército e alunos da Escola Militar do Realengo ficaram ao lado da oposição, dando origem ao tenentismo, desdobrado no episódio do Forte de Copacabana, em I922, na Revolta de São Paulo de I924 e na consequente Coluna Prestes, que durará até o início de 1927, o que explica boa parte do aumento da crise de governança da tradicional política do Brasil na Primeira República, assim como as origens do movimento tenentista. 


\section{1922: ORIGENS DO TENENTISMO E ASCENSÃO DAS LUTAS SOCIAIS}

Na Primeira República, o desenvolvimento capitalista expulsou um grande contingente populacional do campo, formando uma massa de "subassalariados" ou de trabalhadores precarizados, além de uma significativa reserva de força de trabalho barata, marcada pelo desemprego estrutural, criando um forte processo de migração interna entre as cidades, o que resultou em diversos problemas sociais e precárias condições de alimentação, moradia, saúde, educação etc.

Nesse processo de nossa formação econômico-social, a história da luta social tem se contraposto às teses sobre a "índole pacífica" da sociedade brasileira. Muitos segmentos sociais defenderam-se e resistiram, muitas vezes de armas na mão, contra a exploração de classe e a opressão semicolonial, seja através de guerras camponesas (como em Canudos e no Contestado), seja por meio dos movimentos marcados pelo simbólico ano de 1922, através do Modernismo, do tenentismo e da formação do Partido Comunista do Brasil (PCB) (KONRAD, 2006), redinamizando as lutas e greves da classe operária presentes em todo o período e somando-se a um contexto em que as mulheres estavam na linha de frente dos movimentos sufragistas.

Essas condições sociais e políticas geravam contradições entre as frações das classes dominantes que hegemonizaram o poder político em boa parte da Primeira República, bem como causavam dissensos políticos em sua base de apoio, especialmente entre setores da pequena burguesia, particularmente nas camadas médias das forças repressivas do Estado, os militares.

Aqui, se entende melhor o que passou a ser chamado de Reação Republicana, como demonstrou Anita Leocádia Prestes: “Uma articulação formada, em I92I, pelas forças vinculadas aos partidos republicanos do Distrito Federal e dos estados do Rio de Janeiro, Rio Grande do Sul, Bahia e Pernambuco", os quais estavam "insatisfeitos com a escolha do mineiro Artur Bernardes para a sucessão presidencial de Epitácio Pessoa”. Assim, mesmo que derrotada eleitoralmente em 1922, essa frente eleitoral que apoiava o fluminense Nilo Peçanha empolgou "amplos setores das populações urbanas que se mobilizaram contra a política dominante das oligarquias paulista e mineira” (PRESTES, I994, p. I6-I7), expressando conflitos que seriam fundamentais para o surgimento do movimento tenentista.

Mas a Reação Republicana não expressava apenas um conflito entre frações das classes dominantes que governavam o Brasil, muito menos uma aparente luta entre civis e militares. Anita Prestes já observou que, "numa situação de grave crise econômica, social, política e cultural da República Velha, como a que se delineava no início dos anos 20", se criavam "as condições para o surgimento de um clima revolucionário, propício tanto à eclosão das revoltas militares, consubstanciadas no movimento tenentista”, como à "intensa atuação política dos grupos oligárquicos dissidentes" e “das camadas médias urbanas de outros setores de oposição” (PRESTES, I994, p. I8-I9, grifos originais). Concordando com o argumento da historiadora, é impossível entender as revoltas tenentistas de julho de 1922 e julho de I924, desdobradas na Coluna 
Prestes e na articulação para a formação da Aliança Liberal, em 1928, prenúncio do movimento de 1930, se não entendermos o papel da Reação Republicana na própria formação do tenentismo.

Diferentemente do que argumentou Maria Cecília Spina Forjaz, para quem o tenentismo adquiriu um "certo grau de autonomia política, em relação tanto às classes dominantes quanto às classes subordinadas", devido à "inserção das categorias sociais de Estado no aparelho estatal", separando a sociedade política da sociedade civil, em reiterado argumento liberal (FORJAZ, I988, p. 3I), bem como da visão do cientista político José Augusto Drummond, que defende a tese de que o tenentismo, "antes de qualquer outra coisa", foi "uma forma de atuação política do Exército Brasileiro, mais exatamente de um Exército dividido por solicitações e projetos políticos conflitantes", ou seja, foi "uma manifestação de militarismo e, enquanto tal, experiência única na história militar brasileira", combinando "busca de soluções de força para problemas políticos nacionais", "ausência da proposta de um governo militar", "participação exclusiva de uma parte da juventude militar" e "grande isolamento político inicial" (DRUMMOND, I986, p. 277), esse movimento expressou parte dos conflitos intraclasses do início da década de 1920 e teve relação direta com essa cisão no seio do poder coronelista, que fundamentou a chamada "política dos governadores", sobretudo entre os governos de Prudente de Morais, iniciado em I894, e Washington Luís, encerrado em 24 de outubro de 1930, especialmente durante o final do governo de Epitácio Pessoa, que foi até 15 de novembro de 1922, e o governo de Artur Bernardes, o qual duraria até 15 de novembro de 1926. Foi nesses dois governos que ascendeu e se consolidou o tenentismo, bem como se desenvolveu boa parte da Coluna Prestes.

Mesmo como um fenômeno histórico delimitado por um tempo cronológico curto (1922-I935), como explica Carone (I975, p. IO), o tenentismo foi parte de um processo mais amplo dos movimentos sociais e políticos revolucionários, não no sentido de uma revolução social, como passou a defender o Partido Comunista, também originário de 1922, mas de uma revolução política difusa que empurrava sobretudo a jovem oficialidade radicalizada para uma solução de força, com o objetivo de tomar os quartéis e derrubar os governos que consolidaram a "política café com leite".

Com ideologia difusa, mais moralista do que classista, os "tenentes" passaram a se indignar com as constantes fraudes no sistema eleitoral, oriundas do voto de cabresto, que fundamentavam nas localidades o poder central dos coronéis na capital federal. Antecedem o episódio as cartas supostamente escritas por Artur Bernardes atacando os militares, as quais geraram forte reação em setores importantes do Exército, envolvendo Hermes da Fonseca, ex-presidente da República e agora presidente do Clube Militar, bem como seu filho, igualmente militar, Euclides da Fonseca, tensionando desde I92I o processo eleitoral para a Presidência da República, cujo desfecho não terminaria no pleito de $\mathrm{I}^{\mathrm{O}}$ de março de $\mathbf{1 9 2 2 .}$

Vencedor das eleições, Bernardes foi proclamado presidente em 7 de junho, disso logo resultando mais protestos da Reação Republicana, especialmente com re- 


\section{Como já escreveu João Quartim de Moraes, "a rebelião dos 'tenentes' constitui um episódio de rara densidade ético-cívica em nossa história política"}

beliões populares em Pernambuco e com ordens de repressão ao movimento dadas pelo governo central, aumentando o protesto no seio militar e a contrariedade de Hermes da Fonseca, o que resultou em sua prisão e no fechamento do Clube Militar.

Era o que bastava para que jovens oficiais passassem a defender a reação com armas na mão, a fim de derrubar Epitácio Pessoa antes mesmo da posse de Bernardes. Assim, irrompeu o chamado Levante do Forte de Copacabana, ou Revolta dos I8 do Forte, em 5 de julho de 1922, liderado justamente por Euclides da Fonseca, que era capitão e comandante dessa unidade militar. Com apoio dos tenentes Siqueira Campos, Eduardo Gomes, Newton Prado, Mário Carpenter e outros militares, a marcha, que buscava atravessar a avenida Atlântica, teve o apoio de um civil, Otávio Corrêa, mas foi violentamente alvejada por tropas legalistas entre o Forte de Copacabana e o Leme, para onde se dirigiam de armas na mão os revoltosos, restando vivos apenas os dois primeiros (há muitas controvérsias na historiografia sobre o número exato de participantes da marcha, cuja maioria foi morta em combate), além de outros dois soldados. Antes mesmo da marcha, 272 militares que estavam no forte se renderam, outros mais desistiram da marcha, enquanto Euclides da Fonseca foi preso ao tentar negociar com o ministro da Guerra, o civil João Pandiá Calógeras, assim como o forte foi intensamente bombardeado pela Fortaleza de Santa Cruz, na baía de Guanabara.

A revolta heroica do Forte de Copacabana, enfrentando mais de 3 mil militares legalistas e que durou até o dia seguinte, devido à mobilização na Vila Militar e na Escola Militar de Realengo, buscando derrubar a República Velha, resultou em grande repressão aos jovens oficiais, mas não debelou sua mobilização política.

Ao contrário. A estratégia do Exército de afastar os "tenentes" do eixo político na capital federal fez com que os jovens rebeldes fossem transferidos para os mais longínquos locais do país, incluindo a Amazônia e o Rio Grande do Sul, de onde sairiam, exatamente dois anos mais tarde e em um novo Cinco de julho, a Comuna de Manaus e a Divisão Rio Grande, comandada pelo capitão Luiz Carlos Prestes, a partir de Santo Ângelo, no Rio Grande do Sul, marcha que contou com a adesão de muitos "maragatos" derrotados na Revolução de 1923, no Rio Grande do Sul, mas que não aceitaram o Pacto de Pedras Altas, assinado em I4 de dezembro de 1923, depois de quase 
um ano de luta armada que envolveu os republicanos que apoiavam o presidente do estado, Antônio Augusto Borges de Medeiros, contra os federalistas (maragatos), liderados por Joaquim Francisco de Assis Brasil.

Em I924, o centro inicial da nova revolta tenentista foi a Revolta Paulista, ocorrida na capital do estado de São Paulo, com a pretensão de derrubar o governo de Artur Bernardes. O movimento defendia pautas liberais democráticas, como o voto secreto, Justiça gratuita e igualdade perante a lei, reforma dos métodos da educação pública, reformas tributária e aduaneira, separação da Igreja e do Estado, com liberdade religiosa, e moralização da política, com proibição da reeleição dos presidentes da República e dos presidentes dos estados, cuja pauta estava presente nas "condições de paz" de 17 de julho, assinadas por Isidoro Dias Lopes, e no Manifesto das forças revolucionárias, de 27 do mesmo mês de 1924, publicado em O Estado de S. Paulor, entre outras, objetivando um "governo provisório" e a retomada do poder pelos militares.

Sob a liderança militar de Isidoro Dias Lopes, então comandante da Força Pública de São Paulo, e a liderança política do também militar Miguel Costa, o movimento sofreu intensa repressão, com o bombardeio de São Paulo, sobretudo nos bairros operários, mesmo que os "tenentes" tivessem recusado o apoio do proletariado, resultando em derrota militar que foi acompanhada da decisão da agora Divisão Paulista de marchar em direção ao Paraná, para onde se deslocava a Divisão Rio Grande.

Aqui se formaria a Coluna Prestes, a qual, sob a liderança do Cavaleiro da Esperança desde a saída do Rio Grande do Sul, com o objetivo de chegar à capital federal, já vinha se utilizando da tática de guerra de movimento, a mesma praticada ao longo da República pelos maragatos rio-grandenses. É importante lembrar que o Exército Brasileiro, bem como as polícias militares estaduais, ao menos até o fim da Primeira Guerra Mundial (I9I8), combatia os inimigos com a "guerra de posição". Assim, a "guerra de movimento" ou tática de guerrilha, proposta por Luiz Carlos Prestes, foi fundamental para que as tropas governistas não conseguissem impor derrotas significativas nem impedir a marcha da coluna.

Ainda na "capital missioneira”, em 29 de outubro de I924, foi lançado o manifesto Povo de Santo Ângelo. Como demonstra Amílcar Guidolim Vítor, "o texto do manifesto de Santo Ângelo iniciava-se com um apelo, exposto na seguinte frase: 'É chegada a hora solene de contribuirmos com nosso valoroso auxílio para a grande causa nacional'". No manifesto, os revolucionários exigiam que o voto do povo fosse secreto, que a vontade do povo fosse uma verdade respeitada nas urnas, que fossem "confiscadas as grandes fortunas feitas por membros do governo à custa dos dinheiros do Brasil" e que os governos tratassem "mais do auxílio ao povo laborioso", que vivia "trabalhando honestamente pela grandeza do Brasil" (VÍTOR, 202I, p. II3)2.

Em paralelo, a revolução tenentista se espalhou pelo país, com destaque para Mato Grosso, Sergipe e Amazonas. Em Manaus, como mostra Anita Leocádia Pres-

1 Ver as condições e o manifesto em Carone (1975, p. 276-279).

2 Como se pode ver também no panfleto-manifesto (PRESTES, 2009, p. 84; CARONE, 1975, p. 298-300). 
tes, "os rebeldes que assumiram o poder em julho de 1924, nele permanecendo por mais de um mês, chegaram a proclamar e pôr em prática algumas medidas de caráter social e nacionalista", com destaque para a tributação dos ricos para remunerar os pobres e a estatização de duas companhias inglesas, mas que "foram rapidamente neutralizadas com o esmagamento da revolta amazonense pelas tropas governistas" (PRESTES, I997, p. 96).

A marcha da Coluna Prestes representou o auge armado do movimento tenentista, quando Aníbal Benévolo e Prestes (junto com o tenente Mário Portela) revoltaram-se quando atuavam, respectivamente, na Brigada de Cavalaria de São Borja e no I ${ }^{\mathbf{o}}$ Batalhão Ferroviário de Santo Ângelo, sendo seguidos por militares de São Luiz Gonzaga, Uruguaiana e a mesma São Borja, tendo à frente os militares Pedro Gay, Juarez Távora (aqui, com apoio do maragato Honório Lemes) e Rui Zubaran (auxiliado por Siqueira Campos, desde o seu exílio na Argentina). Logo depois, rebelaram-se batalhões do Alegrete, sob o comando de João Alberto Lins de Barros, e de Cachoeira do Sul.

Ao romper diversas vezes o cerco legalista, mesmo com muitas baixas, como a do tenente Mário Portela Fagundes, em Pinheirinho do Vale, em janeiro de I925, a coluna conseguiu sair do Rio Grande do Sul, atravessou Santa Catarina a pé (pois havia perdido quase todos os cavalos na travessia do rio Uruguai) e se estabeleceu provisoriamente em Foz do Iguaçu, no Paraná. Ali, com a chegada da Divisão Paulista, em I2 de abril, Prestes, Isidoro Dias Lopes e Miguel Costa formaram a I ${ }^{\mathrm{a}}$ Divisão Revolucionária da Coluna Costa-Prestes, articulada por quatro destacamentos comandados por Siqueira Campos, João Alberto Lins de Barros, Cordeiro de Farias e Djalma Dutra.

Dali em diante, se consolidaria uma das mais gloriosas marchas da humanidade, chamada pela filha de Luiz Carlos Prestes com a revolucionária Olga Benário, a historiadora Anita Leocádia Prestes, de "uma epopeia brasileira" (PRESTES, 2009).

Sempre com o objetivo, não consolidado, de chegar ao Rio de Janeiro e derrubar o governo, a Coluna Prestes durou mais que o mandato de Artur Bernardes, saindo do Paraná, adentrando o Paraguai, voltando ao Brasil por Mato Grosso e rumando a Goiás, Minas Gerais, o atual Tocantins, Maranhão, Piauí, Ceará, Rio Grande do Norte, Paraíba, Pernambuco e Bahia, retornando a Mato Grosso, pelo Pantanal, de forma invicta, até o exílio de seus integrantes, na Bolívia, em 3 de fevereiro de I927. Apenas para se ter uma ideia comparativa, a marcha liderada por Mao Tsé-tung e Zhou Enlai, composta por Ioo mil participantes (30 mil soldados e 70 mil camponeses), entre I6 de outubro de 1934 e 20 de outubro de I935, percorreu I2,5 mil km, enquanto a Coluna Prestes percorreu o dobro desse percurso.

Assim, como indica Anita Leocádia Prestes, se o tenentismo "foi o fruto mais evidente da crise política da República Velha, a Coluna Prestes marcou a década de I920 como o momento culminante das revoltas tenentistas, o episódio mais importante da saga dos 'tenentes”. Em seus dois anos e três meses de duração, com cerca de I,5 mil homens e 50 mulheres, sem ter sido derrotada, transformou-se num "exército com características populares, cuja marcha pelo Brasil foi decisiva para que a chama 
Se a Primeira República havia começado com um golpe, terminaria com outra ruptura, mesmo que a ruptura por golpe de Estado tivesse avançado, no primeiro caso, para uma república, e, no segundo caso, para uma república social, garantindo direitos sociais e trabalhistas e implantando reivindicações históricas das classes trabalhadoras

da revolução tenentista se mantivesse acesa". Apesar de ser "uma marcha militar", ela "adquiriu as características de movimento popular", agregando trabalhadores do campo e lutando "pela liberdade e pela justiça para o povo brasileiro, ainda que esses conceitos fossem vagos e imprecisos na mente de homens humildes e rudes" (PRESTES, 2009, p. I29-130).

Como já escreveu João Quartim de Moraes, “a rebelião dos 'tenentes' constitui um episódio de rara densidade ético-cívica em nossa história política", bem como "na história do Exército Brasileiro", haja vista que "assinala o momento em que mais fortes foram em suas fileiras os partidários de uma ruptura revolucionária da ordem social injusta imposta ao país pela oligarquia latifundiária", especialmente "contra a corrupção eleitoral, atraso cultural, a miséria social e as demais consequências perversas de um sistema político formalmente republicano" (MORAES, I99I, p. I35). Antes do seu fim, ainda ganhou um novo fôlego, através de levantes militares em Bagé e São Gabriel, logo debelados, mas suficientes para estourar a Coluna Relâmpago, quando, em Santa Maria, primeiro no $5^{\circ}$ Regimento de Artilharia Montada, depois, na madrugada de I6 de novembro de I926, quando a cidade "foi acordada com toques estridentes de clarim" e "os primeiros tiros de canhão foram disparados na frente do $7^{\circ}$ Regimento de Infantaria", no fim da atual rua Dr. Bozzano, cujos "alvos eram posições legalistas no centro da cidade" (RITZEL, 2020), os irmãos Alcides e Nelson Etchegoyen lideraram a sublevação militar, tentando impedir a posse de Washington Luís. Era um novo momento tenentista,

contido após ásperos combates em que também se envolveram novas colunas formadas por rebeldes exilados, que cruzaram a fronteira para apoiar o levante, gerando uma situação em que a sorte das armas permaneceu algum tempo indecisa, o que levou o general Isidoro, o qual, nesse momento, estava com suas tropas estacionadas no Paraguai, a solicitar à Coluna Prestes que prosseguisse sua luta 
mais dois meses, numa última tentativa de reacender a rebelião em escala nacional (MORAES, I994, p. 33).

A Coluna Prestes deixou sementes, no sentido dado por Nelson Werneck Sodré ao afirmar que, para se entender o papel desta como "episódio culminante do tenentismo", qualquer um que "ignorasse [...] que cada etapa histórica contém o germe da seguinte estaria incidindo em profunda incompreensão do processo" (SODRÉ, s.d., p. 59-6o).

Assim, o fim da Coluna Prestes não ocorreu com a crise política da Primeira República, muito menos com as articulações tenentistas para derrotar a República das Oligarquias, como defendia o movimento. Como se sabe, não seria diferente com o Partido Comunista. Submetido a rigorosa ilegalidade e clandestinidade desde o governo de Artur Bernardes, com repressão continuada após Washington Luís assumir, em I927, os comunistas brasileiros organizaram o Bloco Operário e Camponês (BOC), articulado para a ação legal e eleitoral, chegando a ter candidato à Presidência da República em 1930, o primeiro candidato presidencial operário e negro da formação social do Brasil, Minervino de Oliveira. Marmorista, Minervino já havia sido eleito, pelo BOC, intendente da cidade do Rio de Janeiro, em I928, bem como secretário-geral da Confederação Geral dos Trabalhadores do Brasil (CGTB), criada em abril de 1929. Aliás, essas articulações igualmente demonstram que o tenentismo era um movimento político e social que, como indicou Anita Leocádia Prestes, "não foi militarista, nem esteve isolado da sociedade brasileira da época", pois manteve, "em maior ou menor grau, contato com os diferentes setores sociais e políticos em oposição aos grupos dominantes da burguesia cafeeira - as frações oligárquicas dissidentes, as camadas médias urbanas e elementos do operariado" (PRESTES, I997, p. 98).

No exílio na Bolívia, Astrojildo Pereira, em nome do Partido Comunista, vai ao encontro de Luiz Carlos Prestes, levando algumas obras marxistas para o Cavaleiro da Esperança. O grande líder brasileiro iniciava ali a aproximação com o comunismo, ao qual se manteria fiel até o fim da vida, pois, como indicou Carone, essa segunda fase do tenentismo, a do exílio, aparentemente ambígua, concretizava "as opções e os caminhos da revolução", explicitando que não existe tenentismo, mas "tenentismos" (CARONE, I975, p. II-I2, grifos originais). Nela, o tenentismo se dividirá em duas alas: uma, que apoiará a "revolução política" com as frações burguesas, na qual estarão Juarez Távora, João Alberto, Siqueira Campos, Cordeiro de Farias e outros, e que desembocará na articulação à esquerda em I930; outra, a da "revolução social", que levará parte do tenentismo ao comunismo, tendo Prestes à frente, expressa por seu Manifesto de maio de 1930.

\section{TENENTISMO E MOVIMENTO DE 1930}

No Rio Grande do Sul, em I928, sucedendo Borges de Medeiros na Presidência do estado, entrou em cena Getúlio Vargas, ex-ministro da Fazenda do governo Wa- 


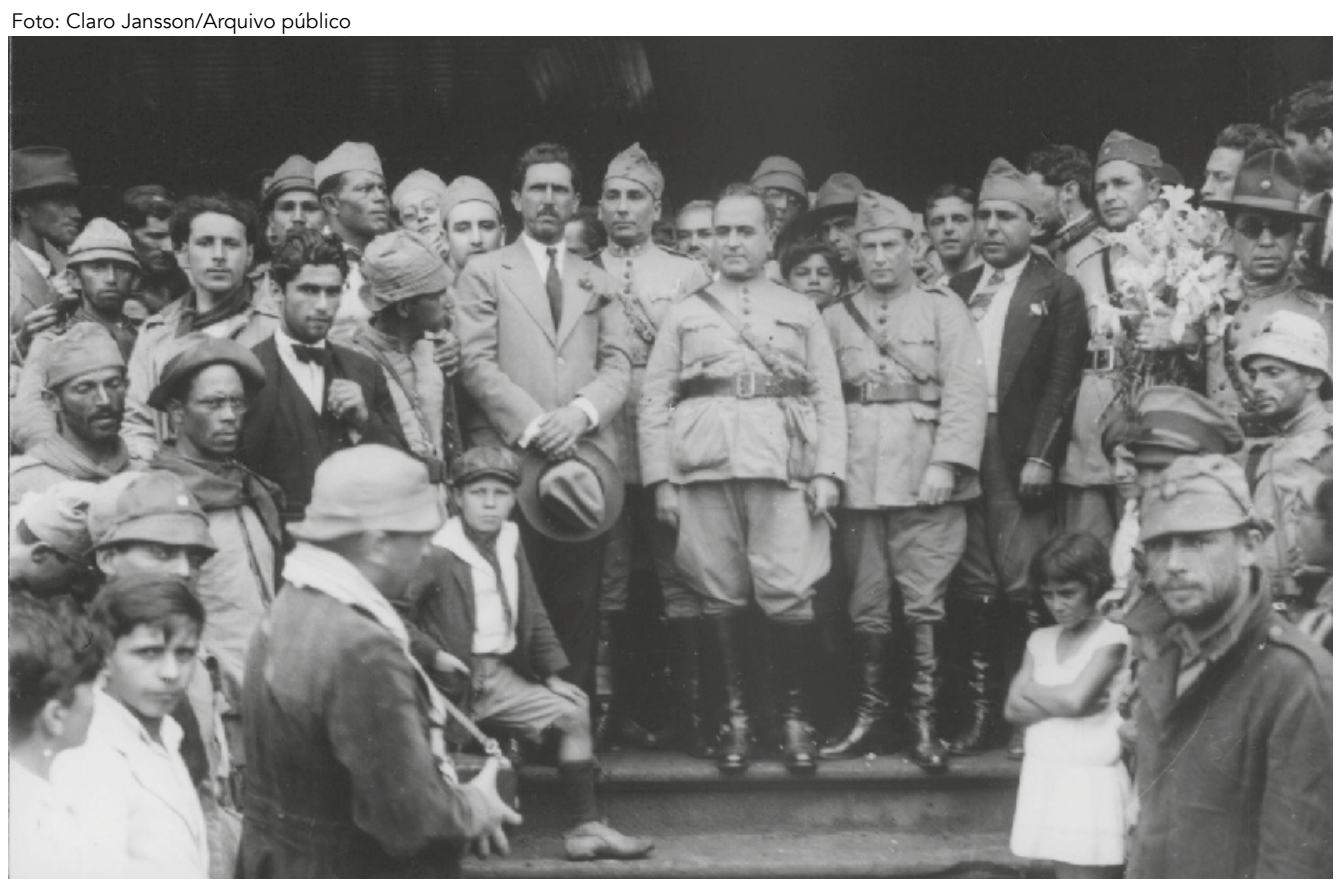

Getúlio Vargas com outros líderes da Revolução de 1930 em Itararé (SP) logo após a derrubada de Washington Luís

shington Luís (I926-I930), eleito pela unidade da Frente Única Gaúcha (FUG), coligando governo e oposição liberal conservadora. O Partido Republicano Rio-Grandense (PRR), em aliança com o Partido Libertador (PL), formava a base política da Aliança Liberal (AL) que lançaria o próprio Vargas candidato à Presidência nas eleições nacionais de I930 (KONRAD; LIMA, 20I3, p. 6I).

Com a vitória eleitoral de Júlio Prestes, Getúlio Vargas, mesmo com vacilações iniciais, foi convencido a não aceitar a derrota, e, junto com a dissidência mineira e paraibana, sob a alegação de fraude eleitoral e com apoio da maioria tenentista, movimentou-se para a derrubada do governo de Washington Luís, iniciando o Governo Provisório e dissolvendo o Congresso Nacional e as assembleias estaduais já em II de novembro de 1930. Segundo Neill Macaulay, "era natural que os membros da Revolução de 1930, que proclamavam ideias liberais, tentassem recrutar os heróis da Coluna Prestes. Do alto-comando da coluna, apenas Luiz Carlos Prestes, que se dedicava ao estudo do marxismo-leninismo na Argentina, rejeitou o apelo às armas em 1930" (MACAULAY, I977, p. 229).

Assim, se a Primeira República havia começado com um golpe, terminaria com outra ruptura, mesmo que a ruptura por golpe de Estado tivesse avançado, no primeiro caso, para uma república, e, no segundo caso, para uma república social, garantindo direitos sociais e trabalhistas e implantando reivindicações históricas das classes trabalhadoras (KONRAD, 2015a). Soma-se a isso que a maioria tenentista que vai apoiar o movimento de 1930, além do liberalismo radical, também defendia um projeto industrializante para o Brasil, de forma mais radical que a própria Aliança Liberal. 
Para dar sustentação política a esse período do Governo Provisório, a maioria dos "tenentes" vai estar na linha de frente, seja organizando as Legiões Revolucionárias junto com Osvaldo Aranha, Plínio Salgado e outros, seja criando o Clube 3 de Outubro, sustentáculo paralelo do governo Vargas, ao menos até o fim da Constitucionalista de 1932, seja participando das interventorias nos estados (SILVA, 1972), até a derrota final do movimento, quando Getúlio promove uma conciliação durante o processo constituinte (I933-I934), visando à sua manutenção no governo.

Com o movimento de 1930 e a chegada da oposição oligárquica ao governo (KONRAD, 20I3, p. 93-I05), ocorrida em 24 de outubro, começou o processo mais acentuado de um modelo econômico de desenvolvimento nacional e autônomo (KONRAD, I987, p. 38). A crise econômica de 1929 afetara a economia do país como nunca, fazendo com que os preços baixassem de forma brutal, especialmente, em razão do aumento dos estoques, o preço do café — nosso principal produto de exportação —, ao mesmo tempo que ocorreu uma retração do mercado, gerando contínuos impasses para a agricultura, a pecuária e o comércio e aumentando as dívidas (KONRAD; RAMOS, I988, p. 3I).

Em termos políticos, 1930 tinha dívidas profundas com as reivindicações de moralização das eleições, uma das principais reivindicações do movimento tenentista, o qual marcara a década de 1920, somando-se aos pleitos de reforma da Constituição de ı89ıe da legislação eleitoral vigente e herdada da Primeira República.

Uma das primeiras medidas do Governo Provisório foi a criação do Ministério do Trabalho, Indústria e Comércio (MTIC). Getúlio Vargas e outros líderes do novo governo, como Lindolfo Collor, em constantes discursos e manifestações públicas, reiteravam a máxima de que no Brasil "a questão social havia deixado de ser caso de polícia”. Cumpria-se, assim, parte importante da plataforma eleitoral da Aliança Liberal, que, dentre seus pilares, apresentara a diretriz da harmonia social para a solução governamental dos conflitos entre capital e trabalho, tão comuns na época da Primeira República (KONRAD, 2004, p. 32).

O movimento de I930, na verdade, havia representado uma solução incompleta e ambígua dos problemas da Primeira República (KONRAD, 1994, p. 69). As soluções das questões políticas, sociais e econômicas do pós-I930 foram sempre parciais e dirigidas pelos grupos dominantes. Mesmo os "tenentes", com perspectivas industrializantes, através de um nacionalismo exaltado, combinado com um vago anti-imperialismo, numa atuação de caráter moralista, apresentavam "propostas políticas autoritárias e desprezo pelas formas da democracia liberal” (VIANNA, 1992, p. 24).

A Revolução de 1930 trouxe a "modernidade" burguesa para o Brasil. A consolidação do trabalho livre, urbano e mecanizado, como uma das bases de sustentação econômica, pôde aproximar as conclusões sobre o período pós-I930. Porém, a "modernização", que implicava também os pilares políticos clássicos da modernidade burguesa, baseados na igualdade de direitos e na democracia participativa, ainda encontrou dificuldades para criar raízes nesse período (KONRAD, 2004, p. 200-20I). 
Momentaneamente, parecia que novos ventos de liberdade, para os que estiveram na oposição naqueles últimos anos, soprariam sobre o Brasil. Em 8 de novembro, com o decreto $\mathrm{n}^{\circ}$ 19.395, o governo concedeu a anistia a todos os implicados em movimentos revolucionários do país, fossem políticos ou militares, competência cabível apenas ao Poder Legislativo durante a vigência da Constituição de I89I. Particularmente, eram atingidos pelo decreto os "tenentes" de I922, de I924 e da Coluna Prestes.

Por outro lado, anunciava-se a punição dos líderes do regime anterior. As prisões dos ex-integrantes do governo continuaram, sendo que, inicialmente, muitos foram declarados incomunicáveis, com o status de presos políticos. Em Io de novembro, apareceram os primeiros deportados, quando, através do decreto $\mathrm{n}^{\circ} \mathrm{I9} \cdot 398$, de II de novembro de 1930, o governo passava a exercer os poderes Executivo e Legislativo conjuntamente, sendo que o artigo $5^{\circ}$ estabelecia a suspensão das garantias constitucionais (o parágrafo único estabelecia que não teriam direito ao habeas corpus os réus funcionais e os sujeitos a tribunais especiais); o artigo I6 criava o Tribunal Especial para os processos e julgamentos dos crimes políticos, funcionais e outros. No dia seguinte, cumprindo promessa, Getúlio Vargas decretou a dissolução do Congresso Nacional, das câmaras estaduais e dos conselhos municipais de todo o país.

As medidas autoritárias se ampliaram com a ideia da criação de Tribunais Revolucionários Especiais. E logo geraram polêmicas, porque visavam atingir os integrantes dos escalões superiores do governo, portanto integrantes das classes dominantes. Quanto aos comunistas, que haviam se oposto ao movimento de 1930 (CARONE, I989, p. 302-9; I982b, p. 83-II9), continuavam inimigos da ordem pública (KONRAD, 2004, p. 156-I59). A permanência de práticas repressivas, por sua vez, rapidamente gerou dissensos em frações das classes dominantes que apoiaram o movimento de 1930, assim como veremos na divisão da base tenentista que apoiara Getúlio.

Logo no início de I932, o Partido Democrático de São Paulo (PD) rompeu com o Governo Provisório, passando a utilizar a tática central da reivindicação da reconstitucionalização do país. Como desdobramento, no dia 25 de janeiro, na praça da Sé, centro da capital paulista, um comício pró-Constituinte reuniu aproximadamente Ioo mil pessoas. Logo depois, em I6 de fevereiro, as classes dominantes paulistas se reorganizam politicamente, reunindo o PD e o PRP e formando a Frente Única Paulista (FUP), em oposição ao governo federal (KONRAD, 2004, p. 208).

Boa parte da classe dominante paulista nunca aceitara o movimento de I930, muito menos a interventoria sob liderança tenentista, que descontentava o PD (KONRAD, 2004, p. I84). Muitos paulistas consideravam o outubro de 1930 como "um atentado moral e inominável crime contra a nação brasileira", crime com "consequências na ordem política e na ordem social", como expressa um autor da época, Renato Jar$\operatorname{dim}$ (JARDIM, I932, p. II-I3).

Pressionado pela oposição liberal-conservadora, em I932, Getúlio assinou o Código Eleitoral e criou a Justiça Eleitoral, regulando as eleições federais, estaduais e municipais, a contragosto de sua base de apoio tenentista, a qual defendia que Getú- 
lio avançasse para uma ditadura. Como conquistas, o código introduziu o voto secreto, o voto feminino e o sistema de representação proporcional. A legislação eleitoral, pela primeira vez, fez referência aos partidos políticos, ainda aceitando a candidatura avulsa.

Em 25 de fevereiro, um dia depois de Vargas ter assinado o Código Eleitoral, foi empastelada uma publicação do jornal Diário Carioca, na sede da empresa, na praça Tiradentes, Rio de Janeiro, sendo feridos vários linotipistas e jornalistas. A invasão do periódico havia sido praticada por uma tropa de 50 militares do I ${ }^{\circ}$ Grupo de Cavalaria Divisionária, ligados ao Clube 3 de Outubro, uma das principais bases tenentistas de sustentação do governo Vargas, fundado no Rio de Janeiro, em fevereiro de I93I, e abertamente contrário à reconstitucionalização do país, bandeira que o jornal passara a defender. Maurício Cardoso, o ministro da Justiça, prometeu punir com rigor os culpados, enquanto Vargas anunciou publicamente que tomara providências nesse mesmo sentido (CARNEIRO, I978, p. I34-I43).

Com esse episódio, os libertadores gaúchos iriam romper com o Governo Provisório, em apoio aos paulistas. Com o ataque ao jornal, Batista Luzardo, chefe de polícia, Lindolfo Collor, ministro do Trabalho, Indústria e Comércio, e Maurício Cardoso, ministro da Justiça, encontraram a justificativa para deixar o ministério de Vargas. Com eles, saíram João Neves da Fontoura, que era consultor jurídico do Banco do Brasil, e mais alguns aliados. No lugar de Luzardo, assumiu Salgado Filho, que comandava a polícia política desde 1930.

A partir desse momento, aliados ao PD de São Paulo, esses líderes políticos rio-grandenses, com o apoio de Borges de Medeiros, aumentaram a mobilização, rumo à oposição liberal conservadora em relação ao governo Vargas. Nesse momento, construía-se a Revolta Paulista de I932. A oposição bandeirante a Getúlio se organizava. Em São Paulo, em 22 de maio, após um comício pró-Constituinte, na praça do Patriarca, no centro da cidade, os integrantes dirigiram-se para a praça Tiradentes, em frente ao quartel do I ${ }^{\circ}$ Batalhão de Polícia, e, depois, para o Quartel-General da Força Pública do Estado, fazendo pequenas manifestações. Na frente do quartel-general, no momento em que um orador, da rua, expunha as aspirações gerais do movimento, iniciou-se um tiroteio violento, com a chegada da cavalaria da polícia, que dispersou a multidão a golpes de espada e a tiros. No dia 23, aconteceu outro grande conflito na praça da República, próximo ao Clube 3 de Outubro, resultando em vários mortos, entre eles os estudantes Martins, Miragaia, Dráusio e Camargo. Em homenagem a esses jovens mortos, foi criada uma guarda paulista, com o nome de MMDC, marca do movimento paulista de I932, cuja sede de recrutamento foi a Faculdade de Direito (SANTOS, I999, p. 2I).

Em 9 de julho iniciou-se o movimento de São Paulo. Como explica Manoel Correia de Andrade, com "o evoluir da crise econômica [...,] a repercussão dos movimentos de reivindicações operárias e a agressividade dos tenentes reunidos no Clube 3 de Outubro", criou-se uma condição que amedrontou “a burguesia rural dos estados 


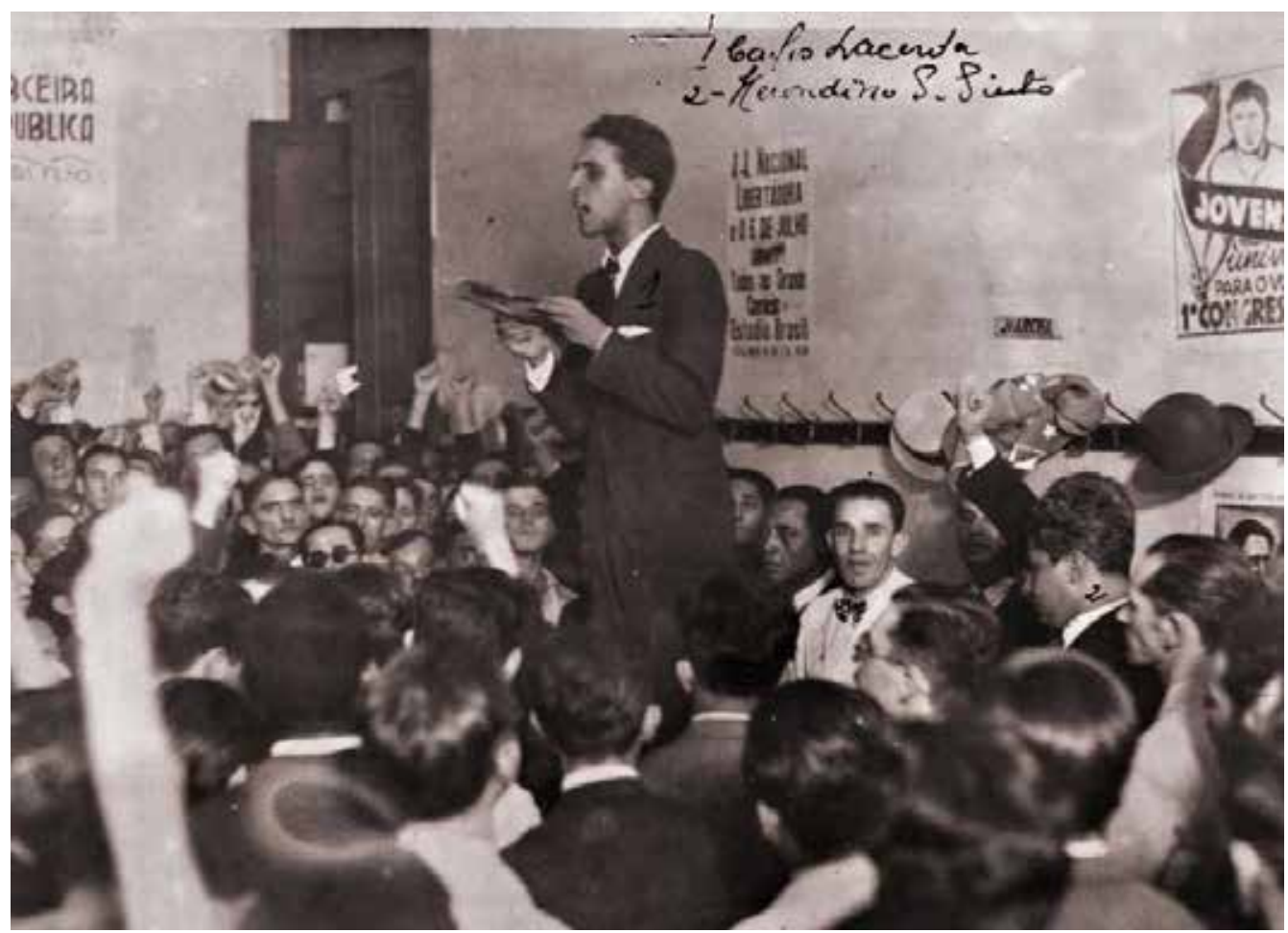

Carlos Lacerda lê mensagem de Luiz Carlos Prestes que termina com a palavra de ordem "Todo poder à ANL!"

mais ricos: São Paulo, Minas Gerais e Rio Grande do Sul”, criando as condições políticas para a conspiração (ANDRADE, I988, p. 65-66).

O rompimento do PL e do PRR com Vargas, assim como o do PD paulista meses antes, tinha, entre outras razões, a maior aproximação do presidente com os "tenentes" do Clube 3 de Outubro, considerados por eles como de esquerda, por serem contrários à reconstitucionalização do país. João Neves da Fontoura chamava-os de "juventude militar extremista", quando não de comunistas.

Iniciada em 9 de julho, a chamada Constitucionalista de $\mathbf{1 9 3 2}$ foi derrotada três meses depois, mas sua reivindicação, a convocação de uma Assembleia Nacio-

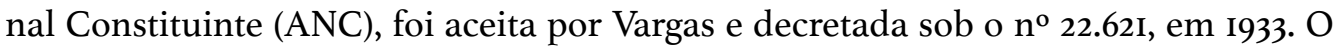
contraste entre a vitória política e militar de Vargas, construída com o apoio de forças militares estaduais e do Exército, com apoio tenentista, e a convocação da Constituinte rapidamente resultou em oposição de vários "tenentes", os quais passaram a chamar o movimento de 1930 de "revolução traída". Alguns deles, ainda em outubro, rumaram à direita, para a Ação Integralista Brasileira (AIB), criada no mesmo mês e liderada por Plínio Salgado.

Convocada a ANC, foi estabelecido que, além dos deputados eleitos na forma prescrita pelo Código Eleitoral, outros 40 seriam eleitos pelos sindicatos legalmente reconhecidos e pelas associações de profissionais liberais e de funcionários públicos. Consolidava-se a representação classista, aos moldes do corporativismo, juntamente como voto das mulheres, pela primeira vez na história brasileira. Como resultado das 
eleições para a ANC, a surpresa foram as eleições de Carlota de Queiroz (primeira deputada mulher) e Álvaro Ventura, militante do Partido Comunista.

Ainda em 1934, o Brasil viveu momentos de agitação política, em parte devido aos trabalhos da ANC e à ameaça de golpe por militares contrários à reconstitucionalização (mesmo após a promulgação da Carta, esses militares continuaram com pretensões golpistas), além da pressão integralista e a consequente dinamização dos movimentos que se opunham a ela. O número de greves aumentou e o governo acenou, no horizonte, com o intuito de controlar a situação e a oposição, com a possibilidade de promulgar uma lei de segurança que barrasse as pretensões da organização popular.

Em 28 de maio de 1934, a ANC votou pela anistia e pela restituição dos direitos políticos dos implicados no movimento de 1932. No mesmo dia, a ANC possibilitou a eleição constitucional de Getúlio Vargas. Dois dias depois, a medida era estendida aos interventores (KONRAD, 2004, p. 288-289), estabelecendo eleições estaduais. Getúlio Vargas foi empossado em 20 de julho de 1934.

Na passagem de 1934 para I935, enquanto o movimento sociopolítico procurava construir greves econômicas e/ou políticas, o governo de Vargas, especialmente com a procura da aprovação de uma lei de segurança, encaminhava medidas para conter qualquer avanço popular.

Em contraposição, passou a crescer no país a organização da ANL, frente antifascista e anti-imperialista, cuja existência foi anunciada no Congresso Nacional ainda em janeiro de 1935. A polícia política acompanhou o lançamento da ANL no Teatro João Caetano, em 30 de março de 1935, relatando que aquela reunião, "cuja assistência encheu literalmente aquele próprio municipal (cerca de 2 mil pessoas)", com a presença de "grande massa proletária, considerável número de pessoas de representatividade social, inclusive oficiais do Exército e da Armada", se caracterizou pelas críticas "mais acrimoniosas" aos governantes de então e à "lei monstro", a LSN, conforme pode se constatar em documento produzido pela polícia política ${ }^{3}$. Era uma conjuntura em que, igualmente, setores militares de oposição de esquerda e tenentista ao varguismo radicalizavam-se a favor da ANL, sobretudo aqueles contrários a uma nova lei de segurança, já chamada por eles de “lei monstro". Em contraposição, tudo que não interessava a Getúlio era pôr em perigo a retomada da hierarquia militar pela cúpula das Forças Armadas, razão da crise final do tenentismo.

A nova LSN, que vinha sendo preparada no Congresso, finalmente foi aprovada em 30 de março e era apoiada por muitos que se consideravam liberais, atitude cuja explicação sintetiza Angela Araújo: “A defesa de princípios liberais pelos setores oligárquicos e pelos segmentos do empresariado urbano que davam sustentação ao governo constitucional mostrou rapidamente a sua incapacidade de conviver com a organização e participação dos setores subalternos", haja vista "o medo da crescente mobilização popular, que se aprofundou e adquiriu contornos políticos mais precisos

3 Cf. Fundo Dops, setor Comunismo, pasta 18-A, folhas 228 a 233, do Arquivo Público do Estado do Rio de Janeiro (Aperj). 


\section{A ANL representou um ponto de convergência do movimento operário autônomo, de organizações antifascistas de imigrantes, da intelectualidade democrática, da oposição parlamentar, de jovens oficiais descontentes com o governo Vargas e com a corporação militar, de frações da burguesia reticentes quanto aos corporativismos e de camadas médias urbanas com ideário liberal-democrático}

com o surgimento da ANL em 1935", levando "os mesmos setores dominantes que se opuseram ferrenhamente às propostas centralizadoras e autoritárias dos tenentes a aprovar medidas de exceção que fortaleciam o Poder Executivo concedendo-lhe poderes discricionários" (ARAÚJO, 1998, p. II8-II9).

A oposição à LSN vinha desde 1934, na mesma conjuntura internacional de fortalecimento do nazifascismo, após a consolidação no poder de Adolf Hitler, na Alemanha. Esse processo, que passou pelo I Congresso Nacional Contra a Guerra Imperialista, a Revolução e o Fascismo (oriundo do Comitê Mundial Contra a Guerra e o Fascismo), ocorrido em 23 de agosto de I934, no Teatro João Caetano, no Rio de Janeiro, teve relação direta com o lançamento da ANL, em I2 de março de I935, quando a comissão de organização provisória organizou o Diretório Nacional Provisório (DNP) da aliança, em reunião realizada em um prédio da avenida Rio Branco, no centro do Rio de Janeiro, o mesmo onde funcionara o Clube 3 de Outubro e que encerrara oficialmente suas atividades em 1933 .

No início de 1935, a situação política do Brasil era cada vez mais tensa, com greves, manifestações e tentativa de aprovação da "lei monstro", a famigerada LSN que tramitava no Congresso desde 1934. A oposição era grande, principalmente de setores das Forças Armadas, que, ao lado de setores progressistas, foram as camadas mais radicalmente contrárias ao projeto, expresso no Manifesto à nação, escrito pelo militar Roberto Sisson, que denunciava a pretensão de "amordaçar a consciência nacional". As reuniões no Clube Militar tornavam-se cada vez mais frequentadas, e 
nelas se apregoavam mudanças no regime de Vargas. Essa situação tornou-se mais crítica nos primeiros meses de I935, por ocasião da discussão sobre o reajuste dos salários dos militares.

A aprovação da LSN, um golpe nas liberdades democráticas da Constituição de I934, coroava os desejos de Vargas e de seus apoiadores de aumentar a coerção e o poder político-policial diante da sociedade. Começava a se fechar o cerco, inicialmente contra os militares aliancistas, em sua maioria de origem tenentista. Ainda no dia 24, a $3^{\text {a }}$ Delegacia Auxiliar de Porto Alegre enviou para a Delegacia Especial de Segurança Política e Social (Desps), na capital federal, os nomes do capitão Francisco Moésia Rolim, que atuava em Pelotas, do capitão Agildo da Gama Barata Ribeiro (vice-presidente da Comissão Provisória da ANL estadual e integrante do $8^{\circ}$ Batalhão de Caçadores de São Leopoldo, tachado de "extremista", certamente pela sua filiação ao Partido Comunista, ocorrida em fevereiro desse ano) e dos primeiros-tenentes Felipe Vianna e Prudente de Castro, dirigentes do diretório de Porto Alegre, todos acusados de ser integrantes da lista dos oficiais aliancistas do Rio Grande do Sul que lideravam a agremiação. Além desses, eram listados os militares José de Andrade Leão (de São Leopoldo), Sílvio Porto Dias (tenente do $7^{\circ}$ RCI de Livramento) e Hugo de Souza Silveira (de Uruguaiana). Juntamente com essa informação, a Desps organizou a lista de outros militares da ANL em atividades organizativas pelo Brasil, como o major Carlos Costa Leite, os capitães André Trifino Corrêa, Amauriti Osório, Haroldo Oest e Antônio Rollemberg (oficiais do Exército) e os comandantes Hercolino Cascardo, Walfrido Caldas e Roberto Faller Sisson, estes, oficiais da Armada.

Por sua vez, o movimento operário, em ascensão, com reivindicações salariais que se avolumavam, fortalecia o movimento. Paralelamente a isso, aumentava também a oposição dos aliancistas contra os integralistas, através de inúmeros confrontos de rua em vários pontos do país. A recessão, a insatisfação popular nos centros urbanos e o permanente estado de agitação no campo aproximavam a "esquerda e os liberais numa mesma estação" (VIANA, 1985, p. I3). Nessa conjuntura, o Estado era controlado por um bloco das classes dominantes, tendo à frente frações da burguesia agrária em decadência e da industrial em ascensão, e por setores da pequena burguesia urbana, composta por políticos profissionais e burocratas civis e militares, originários da oposição à Primeira República, ou que se reintegraram após 1930, mesmo que tivessem participado do poder anteriormente (TAVARES, I985, p. 60).

Esses grupos conservadores começaram a se unir para prostrar os movimentos populares da pequena burguesia e do operariado que ascendiam. As classes dominantes utilizavam-se dos aparatos do Estado para reprimir o operariado, enfrentando o "mal maior", denominado "perigo do comunismo", enquanto os integralistas eram tratados com esmero. Como afirma Edgar Carone, "se o integralismo tranquiliza a burguesia, tentando por um regime de força manter o status quo, a Aliança Nacional Libertadora procura novas soluções para conflitos cada vez mais aguçados", sendo que "março e abril de 1935 marcam acontecimentos políticos fundamentais para a 
lização na perspectiva de mudanças estruturais propostas por alguns liberais, pelos socialistas e pelos comunistas e, por outro lado, pelo pedido de endurecimento do regime, por parte das forças integralistas ou conservadoras. $\mathrm{O}$ processo político radicalizava-se cada vez mais, devido à ausência de soluções para os problemas, tais como aumento da corrupção e maior volume de ações repressivas nos quartéis contra a baixa oficialidade e praças, ou mesmo pela ação da polícia política (OLIVEIRA FILHO, I985, p. XIII).

É nesse contexto que a luta entre esquerda e direita vai assumir aspectos violentos (SODRÉ, I987, p. 327), sobretudo devido às propostas transformadoras para o capitalismo brasileiro originárias da ANL. Edgard Carone entende que os manifestos da ANL servem de teor ideológico ao movimento. De fevereiro a julho, quando são lançados os manifestos, alarga-se o sentido programático, bem como a tática do programa. O que permanece é a ênfase anti-imperialista e antifascista. $O$ programa de união nacional para conquistar o maior número possível de forças dirige-se à busca da gênese de reivindicações nas revoltas tenentistas, iniciadas em I922. Nesse sentido, a ANL tem um caráter inovador e passadista (CARONE, I982a, p. 266). Por sua vez, o Partido Comunista, através do programa da ANL, passava de uma atuação em círculos restritos, na ilegalidade, para uma ampla possibilidade de propaganda para as massas (CARONE, I978, p. 425).

De abril a início de julho, abrem-se sedes da ANL em todo o país. Já em maio, havia I.6oo núcleos da ANL, sendo que só no Distrito Federal existiam 50 mil inscritos. Amplas massas e importantes lideranças, como Miguel Costa, João Mangabeira, Pedro Ernesto, Trifino Corrêa e vários outros líderes "tenentistas", socialistas, liberais e comunistas, aderiram ao movimento. Em maio, as inscrições chegavam a ser de 3 mil pagantes por dia, quando a ANL passava a dirigir greves, organizar manifestações públicas, criar uniões reivindicatórias de direito das mulheres e de trabalhadores agrícolas e, por fim, enviar caravanas ao Norte e ao Nordeste (CARONE, I977, p. II6). A ANL chegou a atuar em 17 estados e 300 cidades e pontos populacionais, reunindo mais de I,5 milhão de ativistas (KOVAL, I982, p. 292). Para se ter uma ideia do crescimento da ANL, note-se a seguinte passagem de Affonso Henriques, tesoureiro nacional da ANL, quanto à dimensão do movimento: "O número de inscrições na capital da República era tão grande que tínhamos de ficar até altas horas da madrugada trabalhando na tesouraria, abrindo fichas, apurando dinheiro, escriturando livros, organizando cômputos estatísticos e planos de ação" (HENRIQUES, s.d., p. 345).

De ampla composição social, a origem política da ANL remonta ao tenentismo e sua ala mais radicalizada, a qual, segundo Roberto Sisson, em um documento sobre a ANL escrito em 1939, "aproximou-se das classes dos trabalhadores nacionais, fato que corrigiu a grande debilidade da ação anterior do Clube 3 de outubro, que era a sua falta de ligação com o proletariado" (SISSON apud VIANNA, I992, p. I23).

Assim, a ANL representou um ponto de convergência do movimento operário autônomo, de organizações antifascistas de imigrantes, da intelectualidade democrá- 


\section{A ANL não foi obra exclusiva de comunistas ou de oficiais ou praças com origem no movimento tenentista. Mas essa articulação entre o Partido Comunista e os remanescentes tenentistas que foram para a esquerda, incluindo a própria organicidade com o partido, seguindo Prestes, foi extremamente significativa para fortalecer a relação entre integrantes do movimento operário e os quartéis}

tica, da oposição parlamentar, de jovens oficiais descontentes com o governo Vargas e com a corporação militar, de frações da burguesia reticentes quanto aos corporativismos e de camadas médias urbanas com ideário liberal-democrático, principal base social aliancista (DEL ROIO, I990, p. 29I).

Robert Levine demonstra que, no Distrito Federal, os quadros da ANL constituíram-se de homens de negócios, profissionais liberais e funcionários públicos (37\%), operários e soldados (52\%) e não classificados (II\%), incluindo $2 \%$ de elementos "rurais" (LEVINE apud CHILCOTE, I982, p. 78). Numa visão restrita, para Leôncio Basbaum, 70\% dos aliancistas eram originários da classe média, pois, para o autor, o operariado e os trabalhadores não tinham participação na Aliança (BASBAUM apud FERNANDEZ, 1985, p. 55). Apesar de insinuações que situam a ANL como um movimento de características tenentistas, inclusive pela grande participação de "tenentes" e de outros militares, para José Augusto Drummond, a ANL era uma "frente ampla" oposicionista civil na qual os "tenentes" se dissolveram e perderam sua identidade estritamente militar (DRUMMOND, 1986, p. 264).

Por sua vez, o manifesto de 5 de julho de 1935, com a consigna "Todo o poder à ANL!", significou um marco representativo na história política do Brasil, pois trouxe para a ANL o movimento tenentista, bem como o símbolo das revoltas de I922 e I924. Com isso, a ANL aproveitou o cinco de julho para comemorar e, cada vez mais, divulgar o seu programa à população; foi quando se organizaram comícios em vários locais do Brasil, ocasião em que Luiz Carlos Prestes, presidente de honra da entidade, lançou o manifesto em nome da Aliança, marcando o início da ofensiva contra o governo constitucional de Getúlio e o começo do fim da legalidade da Aliança. No documento 
de 5 de julho, declarava-se que a ANL era a continuadora dos movimentos tenentistas dos anos 1920, ao mesmo tempo que se pedia a instalação de um governo nacional, popular e revolucionário, incitando a derrubada do governo Getúlio Vargas, o que, para Dario Canale, forneceu o casus belli para o governo desencadear a repressão e, posteriormente, em II de julho de I935, fechar a ANL (CANALE, I985, p. 128).

As alas legalistas da ANL ou se encaminharam para o lado dos setores conservadores ou se posicionaram de forma neutra. A continuidade da ANL coube a uma pequena parte da classe operária, ao Partido Comunista e a um número reduzido de tenentistas. Em 27 de julho, o comandante Hercolino Cascardo, presidente nacional da ANL, foi transferido para São Francisco, em Santa Catarina, e a presidência da ANL ilegal passou ao deputado Octávio Silveira. Grande parte das forças que participaram da ANL afastaram-se, restando no movimento a parte mais combativa. Com o fechamento da sede nacional, o governo resguardou-se, confiscando documentos que seriam usados, mais tarde, para forçar a prova de que o "movimento era financiado do exterior e controlado pelos comunistas” (SKIDMORE, I982, p. 43). Terminava, assim, a possibilidade do caminho legal para a tomada do poder.

Militares e comunistas, dali em diante, prepararam, na clandestinidade, um movimento armado, que surpreendeu vários participantes da ANL. Aos poucos, a concepção tenentista, mesmo no interior do Partido Comunista, começou a preponderar. Como explica Boris Koval, "apesar da evidente queda do movimento democrático de massas, muitos membros da direção da Aliança e do PCB supunham que ocorrera agora 'um pequeno recuo e que se aproximava a hora da ofensiva" (KOVAL, I982, p. 305). Assim, erroneamente, "pinta-se" uma irreal situação política do Brasil e, apressadamente, proclama-se a necessidade de uma revolução nacional-libertadora. "A ideia do assalto amadurece na consciência das grandes massas", disse Prestes na época. Leandro Konder cita uma entrevista da revista Isto É, de 6 de setembro de 1978 , na qual Prestes (apud KONDER, 1980, p. 46) teceu uma autocrítica: "Fazíamos apenas agitação nos quartéis, revelando a visão golpista que tínhamos".

Os documentos da ANL não indicam a luta armada como solução para os problemas do Brasil, mas Prestes e o Partido Comunista começaram a sugerir a insurreição como única alternativa. Os pronunciamentos de Prestes a partir do fechamento da ANL são todos sintomáticos do rumo que se persegue (SODRÉ, I986, p. 57). A certeza do sucesso do movimento iludia os aliancistas restantes durante o período da ilegalidade. Contudo, é certo que faltavam ainda condições objetivas e, mais ainda, subjetivas, para qualquer revolução armada de caráter comunista no Brasil de 1935.

Entretanto, a posição a favor da tomada dos quartéis para derrubar o governo, sobretudo nas alas aliancistas de origem tenentista do Exército, era cada vez mais forte, fazendo com que se pensasse que a classe trabalhadora atenderia aos apelos da ANL ilegal. Contudo, como afirma Marly Vianna, "por mais absurda que hoje possa parecer, a perspectiva de uma vitória insurrecional, em I935, era real para os que viviam a época" (VIANNA, I992, p. I49). Fala-se, claramente, num governo de coalizão 


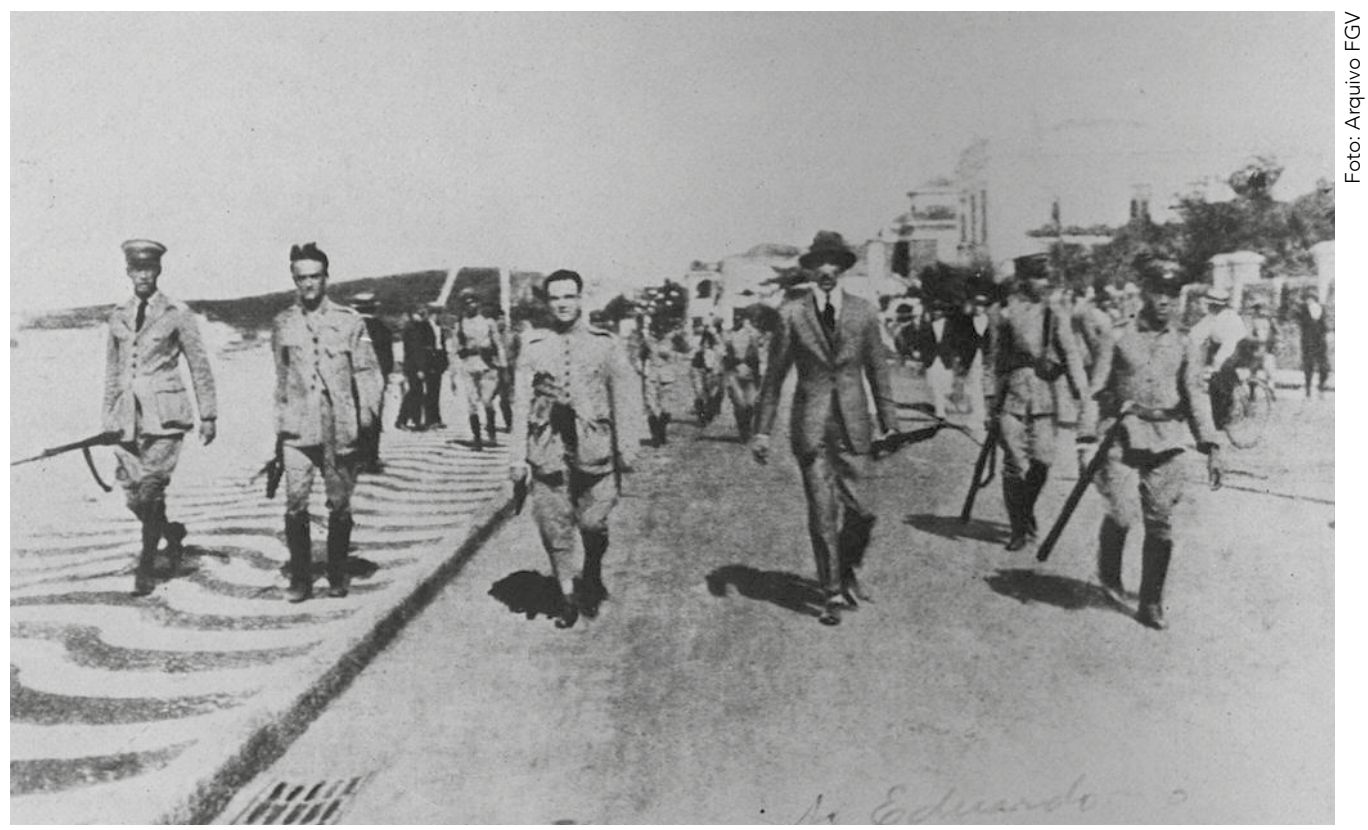

Os 18 do Forte: Os tenentes Eduardo Gomes (à esq.), Mario Carpenter e Newton Prado, o civil Octavio Correia e soldados, após saírem do Forte de Copacabana, 06/07/1922

popular nacional-revolucionário, sob a presidência de Luiz Carlos Prestes e com a participação da Aliança. No período de outubro a novembro, com nova onda grevista, os aliancistas, agora sob o comando total de Prestes e do PCB, opinavam que, mais cedo ou mais tarde, a revolução seria posta na ordem do dia.

Entretanto, os levantes em Natal, Recife e Rio de Janeiro surpreenderam muitos, inclusive do Partido Comunista. A facilidade com que se debelaram os movimentos expressou a ilusão que levou os aliancistas à insurreição nacional libertadora de novembro de I935 (KONRAD, I994, p. II2-II3), com a tática das quarteladas.

\section{TENENTISMO E ANL}

Os "tenentes", ou a jovem oficialidade tenentista, estão no centro dos acontecimentos de 1935. Mesmo que o movimento de 1922 já tivesse perdido fôlego com o fechamento do Clube 3 de Outubro, em 1933, a linha tenentista influenciou, em parte, a ANL, Luiz Carlos Prestes e o PCB, pois, mesmo que a luta por transformações mais radicais estivesse presente na frente antifascista, ela manteve táticas daquele movimento.

Se antes de 1930 setores tenentistas procuraram moralizar os costumes políticos, ao mesmo tempo que pressionaram pela redução das diferenças socioeconômicas, os "tenentes" fardados, enquanto movimento político no pós-I930, uniram-se aos "tenentes civis" em alianças temporárias ou mais prolongadas. Não seria um despropósito deduzir que, em essência, sua ideologia pequeno-burguesa estivesse presente em vários setores da esquerda. Esse idealismo revolucionário e o desejo de transfor- 
mações democráticas fizeram com que os "tenentes" conquistassem reconhecimento nacional, apesar do seu elitismo e de propor uma ditadura militar como meio de obter melhores condições sociais e de livrar o país do imperialismo.

Assim, em 1935, parte dos "tenentes" situava-se em campo político de esquerda, voltados para a proposta de "salvar a revolução traída". Com a ANL, as antigas propostas tenentistas foram mais bem elaboradas, apesar de ainda ficarem vagas as estratégias para a tomada do poder. $\mathrm{Na}$ falta dessa hipótese, preponderava a ideia de tomada militar do poder, como se tentou nos anos I920. Contudo, em I935, a realidade era outra, principalmente porque, com Vargas à frente, as Forças Armadas haviam recomposto a hierarquia militar.

A insatisfação com o encaminhamento político dado ao movimento de 1930 empolgava setores da esquerda ligados às Forças Armadas. Assim, o rompimento com o governo Vargas não tardou. Exemplo disso foi o do presidente da ANL, Hercolino Cascardo, que chegou a ser interventor do Rio Grande do Norte, em I93I e I932. Apesar da diferença de objetivos entre os programas da ANL e do movimento pré-I930, os "tenentes" levaram para a organização uma visão "paternalista, elitista, autoritária e eivada de voluntarismo golpista", como opina Forjaz (apud VIANNA, I992, p. IOI). Com isso, mesmo aqueles que, mais tarde, unir-se-ão ao PCB, não romperam com essas posições dos “tenentes".

Os tenentistas da ANL, mesmo com posição política pequeno-burguesa, tornaram-se militantes radicais da ANL, a ponto de Roberto Sisson ter se referido à pequena burguesia como "a força revolucionária da ANL" (SISSON apud MORAIS, I986, p. 82-83). Por essa razão, José Augusto Drummond não considera a ANL uma organização política tenentista, mas defende a tese de que a Aliança contém a última manifestação ostensiva do movimento tenentista. Como exemplo de tal posição, cita a participação de uma pequena parcela de "tenentes" mais antigos, como Luiz Carlos Prestes, André Trifino Corrêa, Silo Meirelles, Carlos Amoretti Osório, Hercolino Cascardo, João Cabanas, Roberto Sisson, Agildo Barata, Francisco Moésia Rolim, Miguel Costa e outros, que se aliam aos "tenentes" mais jovens, identificados com as lideranças militares dos anos 1920 (DRUMMOND, 1986, p. 263). Por sua vez, Marly Vianna considera que a ANL é, essencialmente, uma continuação do tenentismo (VIANNA, I992, p. 305). No entanto, seria equivocado considerar a ANL apenas como expressão tenentista ou não tenentista, pois, mesmo que certos elementos tenentistas tenham sido incorporados à Aliança, outros novos só apareceram no pós-I930 e se expressaram devido à conjuntura de ascensão nazifascista em nível mundial.

É inegável que é na ANL do período legal que, pela primeira vez, os “tenentes” vão ter uma preocupação em mobilizar o apoio das massas, como opina Drummond. Trata-se, conforme o autor, da passagem de uma prática política militarista de corte arbitral, com o objetivo de modificar as instituições políticas formais, para outra de natureza ideológica, objetivando produzir transformações sociais e econômicas de grande profundidade (DRUMMOND, I986, p. 265). 
A ANL, em forma de frente ampla, com seus limites e contradições, representou um dos grandes momentos de tentativa de mudança estrutural para o Brasil, em defesa da democracia e dos direitos dos trabalhadores, com o caráter extremamente atual de suas consignas antifascistas, antiimperialistas e antilatifundiárias

Essa aproximação com os aliancistas tem como exemplo importante a formação dos núcleos da ANL no Rio Grande do Sul (KONRAD, I994, p. I72-204, 335-343). Em Santa Maria, a primeira cidade a organizar um núcleo aliancista no Rio Grande do Sul, em 24 de maio, o Diretório Municipal Provisório (DMP) teve articulação do capitão Francisco Moésia Rolim, atuante em Pelotas. Nessa cidade do sul rio-grandense, em 3I de maio de 1935, na sede do Sindicato dos Marítimos, em reunião anunciada como atividade da Liga Eleitoral Proletária (LEP), o próprio Moésia Rolim, presidente do núcleo local, expôs o programa da ANL aos simpatizantes locais, assim como fará parte do DMP. Em Porto Alegre (Felipe Vianna, coordenador de organização, e Prudente de Castro Jobim), São Leopoldo (Agildo da Gama Barata Ribeiro, presidente, e José C. Andrade Leão, secretário de propaganda), Santana do Livramento (Sylvio Porto Dias, presidente), Uruguaiana (Hugo de Souza Silveira, presidente), Cruz Alta (Almiro Ilgenfritz, presidente), "tenentes" do Exército estiveram na linha de frente para a organização dos núcleos municipais da ANL. Fossem oficiais do Exército ou com outros postos militares, igualmente compuseram os DMPs.

Em nível nacional, depois de rápida organização e extraordinária ampliação da Frente Ampla, possibilitada pela ANL, 5 de julho foi a data escolhida para os grandes comícios em comemoração de um dos momentos mais significativos do tenentismo, mesmo dia em que Luiz Carlos Prestes lançou o manifesto chamado Todo o poder à ANL. Assim, contraditoriamente, os “tenentes" vão unir tais posições ao seu antigo desejo de derrubar o governo com a tomada de quartéis. Isso se torna evidente após o fechamento da ANL, cujas declarações e documentos dos "tenentes" de esquerda convergiam para soluções de golpes armados, mesmo que o desejo sincero ainda continuasse sendo o de fazer amplas transformações econômicas, políticas e sociais. 
Por sua vez, com a ANL, os "tenentes" de esquerda reencontraram parte de seus objetivos políticos, agora aliados aos setores populares (MALTA, I969, p. 97). Nessa mesma linha de argumento, Décio Saes argumenta que, "no processo aberto pela Revolução de I930, os objetivos políticos do tenentismo nacionalista foram rapidamente esgotados", restando que "um novo impulso político só poderia nascer de seu afastamento do círculo do poder e da redescoberta da própria sociedade". Dessa forma, "a 'ala esquerda' do tenentismo (a de Luiz Carlos Prestes) foi a única facção a buscar esse caminho, tentando encontrar nas classes populares a fonte de uma nova política” (SAES, I984, p. II6).

O descontentamento dos setores militares, devido à inferioridade salarial diante das polícias militares estaduais, à irregularidade dos vencimentos dos praças, às péssimas condições de alojamento nos quartéis e à dificuldade de moradia para os oficiais e suas famílias (PEIXOTO, I960, p. I49), era um primeiro passo político para a revolta. O programa da ANL despertou a consciência para esse lado, enquanto o Partido Comunista soube disputar essa herança no momento em que apoiou suas reivindicações e os "feitos heroicos" e "revolucionários" anteriores a I930 (BORGES, I992, p. 237).

\section{CONCLUSÃO}

Os comunistas dividiram com os "tenentes" a opção da via armada para a conquista do poder após a decretação da ilegalidade da ANL, em II de julho de I935. Prestes foi a ponte de convergência para essa tática. Como mostra Leonardo Guedes Henn,

no VI Congresso [da Internacional Comunista],em I928, continuava-se com a proposição da tática das frentes únicas, mas agora devendo ser operadas apenas com as bases trabalhadoras. A revolução mundial era avaliada como estando em novo período ofensivo. Orientava-se para se colocar em prática a tática da classe contra classe, ou seja, alianças somente com setores operários e contra o inimigo burguês (HENN, 20I2).

Assim, antes da chegada de Prestes ao Brasil, o Partido Comunista demonstrava resistências à ANL, haja vista ainda prevalecer a tática de "classe contra classe" desde o VI Congresso da III Internacional Comunista, apesar de sua aproximação programática. O que os diferenciava, a princípio, é que a Aliança queria a derrubada do governo Vargas, enquanto o PCB queria a organização de um "poder soviético de operários, marinheiros, soldados e camponeses", conforme documento do Bureau Político do Comitê Central do Partido Comunista (Seção Brasileira da Internacional Comunista - SBIC), de abril de I935. O Comitê Central do partido criticava, na oportunidade, os elementos "pequeno-burgueses" e "conciliadores" que faziam parte da ANL, constantemente mencionados em documentos e artigos, como o de Bangu, em A Classe Operária, edição de Iº de maio de I935, referindo-se aos "perigos do nacional-reformismo da ANL" (VIANNA, I992, p. I34-I35). 


\section{Como em 1935, na formação,} composição e proposição da ANL, a tática de frente ampla para projetos alternativos ao país, bem como a defesa da democracia, justamente por seu componente antifascista, mantêm impressionante adequação à atual fase da luta de classes no Brasil

A ANL não foi obra exclusiva de comunistas ou de oficiais ou praças com origem no movimento tenentista. Mas essa articulação entre o Partido Comunista e os remanescentes tenentistas que foram para a esquerda, incluindo a própria organicidade com o partido, seguindo Prestes, foi extremamente significativa para fortalecer a relação entre integrantes do movimento operário e os quartéis, sendo decisiva para a insurreição nacional libertadora de novembro de 1935.

Assim, após a entrada da ANL na ilegalidade, toda a atividade partidária do PCB se voltou mais para a preparação de um levante do que para um trabalho diante das massas trabalhadoras (urbanas e rurais). Os acontecimentos de novembro, em Natal, Recife e Rio de Janeiro, apesar de suas especificidades, prenunciam que as futuras derrotas seriam resultado das perspectivas apresentadas pelo Partido e pelos "tenentes", entre julho a novembro de 1935, trazendo consigo, ainda, as táticas de 1922 e 1924. Apesar do amplo movimento popular nesse período, das tentativas de resistência, da convocação de greves e da tentativa de se manter através da organização Aliança Popular por pão, terra e liberdade, a ANL tornou-se instrumento de levantes nos quartéis, rapidamente derrotados no Rio Grande do Norte, em Pernambuco e no Rio de Janeiro.

De qualquer forma, a ANL, em forma de frente ampla, com seus limites e contradições, representou um dos grandes momentos de tentativa de mudança estrutural para o Brasil, em defesa da democracia e dos direitos dos trabalhadores, com o caráter extremamente atual de suas consignas antifascistas, anti-imperialistas e antilatifundiárias. E a ala mais à esquerda do tenentismo redivivo desembocou com toda a sua força política na Aliança. 
A ANL inspirou amplos setores da população brasileira. De abril a junho de 1935, parte significativa dos brasileiros dividiu-se entre optar pelo aliancismo ou pelo integralismo. Até o final de junho, a ANL atuou na ofensiva. Seus núcleos mobilizavam-se a fim de denunciar um possível golpe e convocar uma grande greve. Expressão de uma luta de classes ainda difusa, mas existente, o movimento cresceu tanto nos quartéis como fora deles. Esse será o "momento máximo da política de massas da Segunda República e exemplo de capacidade organizatória e reivindicatória”, como explica Edgard Carone. Para o historiador, "nunca, até então, um movimento tomara tal amplitude e força", isso "porque segmentos de classes médias, da burguesia e do próprio operariado" lutaram “por programas mais amplos, numa afirmação de nacionalismo e luta contra as forças imperialistas" (CARONE, I977, p. 256).

Sabe-se que a saída histórica para as crises de desenvolvimento no modo de produção capitalista, em sua forma mais reacionária, tem sido a alternativa fascista. Como em I935, na formação, composição e proposição da ANL, a tática de frente ampla para projetos alternativos ao país, bem como a defesa da democracia, justamente por seu componente antifascista, mantêm impressionante adequação à atual fase da luta de classes no Brasil, como já defendido no artigo "Da Aliança Nacional Libertadora (I935) à Frente Ampla" (KONRAD, 20I5b), antes ainda do golpe de 2016.

\footnotetext{
* Professor titular do Departamento e do Programa de Pós-Graduação em História (PPGH) da Universidade Federal de Santa Maria (UFSM). Doutor em História Social do Trabalho pela Universidade Estadual de Campinas (Unicamp).
}

Texto recebido em 14 de outubro de 2021; aprovado em 22 de novembro de 2021. 
ANDRADE, Manuel Correia de. A Revolução de 30: da República Velha ao Estado Novo. Porto Alegre: Mercado Aberto, 1988. (Série Revisão, n. 34.)

ARAÚJO, Angela Carneiro de. A construção do consentimento: corporativismo e trabalhadores no Brasil dos anos 30. São Paulo: Scritta; Fapesp, 1998.

BORGES, Vavy Pacheco. Tenentismo e revolução brasileira. São Paulo: Brasiliense, 1992.

CANALE, Dario. A Internacional Comunista e o Brasil (1920-1935). In: TAVARES, José Nilo (Org.). Novembro de 1935: meio século depois. Petrópolis: Vozes, 1985, p. 93-142.

CARNEIRO, Glauco. Luzardo: o último caudilho. Rio de Janeiro: Nova Fronteira, 1978. v. 2.

CARONE, Edgard. A Primeira República (1889-1930). 3. ed. Rio de Janeiro; São Paulo: Difel, s.d.

A República Nova (1930-1937). 3. ed. São Paulo: Difel, 1982a.

A Segunda República (1930-1937). 3. ed. São Paulo: Difel, 1978.

Classes sociais e movimento operário. São Paulo: Ática, 1989.

O PCB (1922-1943). São Paulo: Difel, 1982b. v. 1.

O Tenentismo. São Paulo: Difel, 1975.

Revoluções do Brasil Contemporâneo (1922-1938). 3. ed. São Paulo: Difel, 1977.

CHILCOTE, Ronald H. PCB: conflito e integração. Rio de Janeiro: Graal, 1982.

DEL ROIO, Marcos. A classe operária na revolução burguesa: a política de alianças do PCB (19281935). Belo Horizonte: Oficina de Livros, 1990.

DRUMMOND, José A. O movimento tenentista: a intervenção política dos oficiais jovens (19221935). Rio de Janeiro: Graal, 1986.

FORJAZ, Maria Cecília Spina. Tenentismo e Forças Armadas na Revolução de 1930. Rio de Janeiro: Forense Universitária, 1988.

HENN, Leonardo Guedes. A virada tática comunista do final da década de 1920: do BOC ao obreirismo. Revista Latino-Americana de História, v. 1, n. 3, mar. 2012. Disponível em: <https://dialnet. unirioja.es/descarga/articulo/6238635.pdf>. Acesso em: 12 out. 2021.

HENRIQUES, Affonso. Ascensão e queda de Getúlio Vargas: o maquiavélico. Rio de Janeiro, Record, s.d. v. 1.

HERNANDEZ, Leila M. G. Aliança Nacional Libertadora: ideologia e ação. Porto Alegre: Mercado Aberto, 1985.

JARDIM, Renato. A aventura de outubro e a invasão de São Paulo. São Paulo: Sociedade Impressora Paulista, 1932.

KONDER, Leandro. A democracia e os comunistas no Brasil. Rio de Janeiro: Graal, 1980.

KONRAD, Diorge Alceno. 1935: a Aliança Nacional Libertadora no Rio Grande do Sul. Dissertação (Mestrado em História do Brasil) - Pontifícia Universidade Católica do Rio Grande do Sul, Porto Alegre, 1994. v. 1, 2015a.

A democracia em construção: eleições no Brasil republicano. PasadoAbierto, Mar del Plata, 1987.

Brasil: desenvolvimento e Nova República. História Caderno, Santa Maria, n. 1, p. 37-50, jun. 
. Da Aliança Nacional Libertadora (1935) à Frente Ampla. Vermelho, 7 jul. 2015b. Disponível em: <https://vermelho.org.br/coluna/da-alianca-nacional-libertadora-1935-a-frente-ampla-2015>. Acesso em: 13 out. 2021.

Movimentos sociais e políticos no Brasil contemporâneo e a eleição de 2006. Vermelho, 7 jun. 2006. Disponível em: <https://vermelho.org.br/coluna/movimentos-sociais-e-politicos-no-brasil-contemporaneo-e-a-eleicao-de-2006>. Acesso em: 8 out. 2021.

O fantasma do medo: o Rio Grande do Sul, a repressão policial e os movimentos sociopolíticos (1930-1937). 2004. Tese (Doutorado em História Social do Trabalho) — Instituto de Filosofia e Ciências Humanas, Universidade Estadual de Campinas, Campinas, 2004.

Política e Poder Legislativo no Rio Grande do Sul republicano — parte 2 (1930-1945): a Segunda República. In: SOARES, Débora Dornsbach; ERPEN, Juliana (Org.). O parlamento gaúcho: da província de São Pedro ao Século XXI. Porto Alegre: Assembleia Legislativa do Estado do Rio Grande do Sul, 2013, p. 93-110.

KONRAD, Diorge Alceno; LIMA, Bruna. Política e Poder Legislativo no Rio Grande do Sul republicano — parte 1 (1889-1930): a Primeira República. In: SOARES, Débora Dornsbach; ERPEN, Juliana (Org.). O parlamento gaúcho: da província de São Pedro ao século XXI. Porto Alegre: Assembleia Legislativa do Estado do Rio Grande do Sul, 2013, p. 55-61.

KONRAD, Diorge Alceno; RAMOS, Glaucia Vieira. A história e a "estória" do Brasil. História Caderno, Santa Maria, n. 2, p. 15-42, jun. 1988.

KOVAL, Boris. História do proletariado brasileiro: 1857 a 1967. São Paulo: Alfa-Omega, 1982.

MACAULAY, Neill. A Coluna Prestes: revolução no Brasil. São Paulo: Difel, 1977.

MALTA, Octavio. Os "tenentes" na revolução brasileira. Rio de Janeiro: Civilização Brasileira, 1969.

MORAES, João Quartim de. A esquerda militar no Brasil: da Coluna à comuna. São Paulo: Siciliano, 1994. v. 2.

A esquerda militar no Brasil: da conspiração republicana à guerrilha dos tenentes. São Paulo: Siciliano, 1991.v. 1.

MORAIS, Fernando. Olga. 11. ed. São Paulo: Alfa-Omega, 1986.

MOTTA, Rodrigo Patto Sá. Introdução à história dos partidos políticos brasileiros. Belo Horizonte: Editora UFMG, 1999.

OLIVEIRA FILHO, Moacyr de. Praxedes, um operário no poder: a insurreição comunista de 1935 vista por dentro. São Paulo: Alfa-Omega, 1985.

PEIXOTO, Alzira Vargas do Amaral. Getúlio Vargas, meu pai. Porto Alegre: Globo, 1960.

PRESTES, Anita Leocádia. A Coluna Prestes. 4. ed. Rio de Janeiro: Paz e Terra, 1997.

Os militares e a Reação Republicana: as origens do tenentismo. Petrópolis: Vozes, 1994.

Uma epopeia brasileira: a Coluna Prestes. 2. ed. São Paulo: Expressão Popular, 2009.

RITZEL, Ricardo. A Batalha de Santa Maria. Claudemir Pereira, 13 jun. 2020. Disponível em: <https:// claudemirpereira.com.br/2020/06/artigo-ricardo-ritzel-superagitados-anos-20-conturbacao-nacional-e-a-batalha-de-santa-maria>. Acesso em: 9 out. 2021.

SAES, Décio. A formação do Estado burguês no Brasil (1888-1891). Rio de Janeiro: Paz e Terra, 1985.

Classe média e sistema político no Brasil.São Paulo: T. A. Queiroz, 1984. 
SANTOS, Viviane Teresinha dos. Os subversivos das arcadas. In: CARNEIRO, Maria Luiza Tucci (Org.). Inventário Deops: módulo II. São Paulo: Arquivo do Estado; Imprensa Oficial, 1999.

SILVA, Hélio. 1931: os tenentes no poder. Rio de Janeiro: Civilização Brasileira, 1972.

SKIDMORE, Thomas. Brasil: de Getúlio a Castelo. 9. ed. Rio de Janeiro: Paz e Terra, 1982.

SODRÉ, Nelson Werneck. A Coluna Prestes. São Paulo: Círculo do Livro, s.d.

A Intentona Comunista de 1935. Porto Alegre: Mercado Aberto, 1986. (Série Revisão, n. 26.)

Formação histórica do Brasil. 12. ed. Rio de Janeiro: Bertrand Brasil, 1987.

TAVARES, José Nilo. 1935: reavaliação de análise. In: (Org.). Novembro de 1935: meio século depois. Petrópolis: Vozes, 1985, p. 35-91.

VIANA, Francisco. O dia em que o trem da história atrasou, ou a armadilha de 1935. In: TAVARES, José Nilo (Org.). Novembro de 1935: meio século depois. Petrópolis: Vozes, 1985, p. 11-36.

VIANNA, Marly de Almeida Gomes. Revolucionários de 1935: sonho e realidade. São Paulo: Companhia da Letras, 1992.

VÍTOR, Amílcar Guidolim. A Coluna Prestes 60 anos depois: disputas em torno do passado e construção do patrimônio cultural na Região das Missões do Rio Grande do Sul. 2021. Tese (Doutorado em História) — Universidade Federal de Santa Maria, Santa Maria, 2021. 